\title{
The Correlation and Relationship Between Diameter Increment and Climatic Elements in a Secondary Forest of Universiti Malaysia Sarawak, Malaysia
}

\author{
Karyati Karyati ${ }^{1, *}$, Isa B. Ipor ${ }^{2}$, Ismail Jusoh ${ }^{2}$, and Mohd. Effendi Wasli ${ }^{2}$ \\ ${ }^{1}$ Faculty of Forestry, University of Mulawarman, Indonesia. \\ ${ }^{2}$ Faculty of Resource Science and Technology, Universiti Malaysia Sarawak, Malaysia. \\ *Corresponding author.Email: karyati@fahutan.unmul.ac.id
}

\begin{abstract}
Climatic elements play important roles in the growth of plants. The aims of this study were to determine correlation and relationship between plant growth and climatic elements (rainfall, rainy days, temperature, relative humidity, and solar radiation) in a secondary forest of Universiti Malaysia Sarawak (Unimas), Sarawak, Malaysia. The plant growth was indicated by diameter at breast height (DBH) of some selected tree species. The DBH increment of 30 selected trees which consisted of nine species (Acacia mangium, Cratoxylum arborescens, Cratoxylum glaucum, Endospermum diadenum, Euodia glabra, Macaranga gigantea, Macaranga triloba, Vernonia arborea, and Vitex pubescens) was recorded monthly through the use of Series 5 Manual Band Dendrometer for a period of 1 year. The result showed that increments of several selected species were positively and negatively correlated to one or more climatic elements. The relationship between DBH increment of E. diadenum and climate elements were significant.
\end{abstract}

Keywords: Climatic Elements, Diameter Increment, Fast Growing Species, Secondary Forest

\section{INTRODUCTION}

The growth rate of trees in tropical forests reflects the variation in life history strategies that affect determining species' distributional limits, setting limits to timber harvesting and controlling carbon balance of the stands [1]. The duration to develop a stand and transit it from one stage to another varies among forest communities at different developmental stages [2].

Climate is the strongest driver of spatial variation in tree growth, and that change in climate may, therefore, have large consequences on forest productivity and carbon sequestration [3]. Species-inherent and resource factors as well as considerable variation in stand-level growth of trees resulted from site-climate interactions [4]. Large variances in diameter increment could be associated with high covariance between increment and basal area at the end of the growth period [5]. Seedlings and saplings experience strong growth when increased light is available [6].

The amount of rainfall and average diurnal temperature in a growing season are important to explain variations in tree diameter growth. The variation in diameter growth is mostly by climatic elements [7]. Temperature has a greater influence than rainfall for most of the tree species. In addition, a linear and significant relationship was obtained between precipitation and height-diameter relationships for seven of the 44 tree species studied [8]. The diameter increments of trees have a negative correlation with temperature and rainfall in certain months [9].

The previous study reported that average $\mathrm{DBH}$ increments for nine selected species, namely: Buch.Ham., Cratoxylum glaucum Korth, Endospermum diadenum (Miq.) Airy Shaw, Euodia glabra (Bl.) Bl., Macaranga gigantea Mull. Arg., Macaranga triloba Mull. Arg., and Vitex pubescens Vahl. In the secondary forest were $0.75 \mathrm{~cm}$ year-1 [10]. However, there is need to understand the correlation and relationship between DBH increment and climatic elements. The objectives of this study were to determine correlation and relationship between DBH increment of nine selected tree species and climatic elements (rainfall, rain days, temperature, relative humidity, and solar radiation) in a secondary forest.

\section{MATERIALS AND METHODS}

\subsection{Study sites}

The study was carried out at secondary forest of Universiti Malaysia Sarawak (UNIMAS) $\left(01^{\circ} 28.111^{\prime} \mathrm{N}\right.$ $\left.110^{\circ} 26.234^{\prime} \mathrm{E}\right)$ in Kota Samarahan, Sarawak, East Malaysia as illustrated in Figure 1. The study plot was 
similar with reported by [10]. The plot was established in the secondary forest which is estimated to be existing for more than 30 years after shifting cultivation [10]. The average annual rainfall, rain days, temperature, and relative humidity of this site were found to be 4,323.3 $\mathrm{mm}$ year $^{-1}, 247$ days, $26.3^{\circ} \mathrm{C}$, and $85.3 \%$, respectively [11].

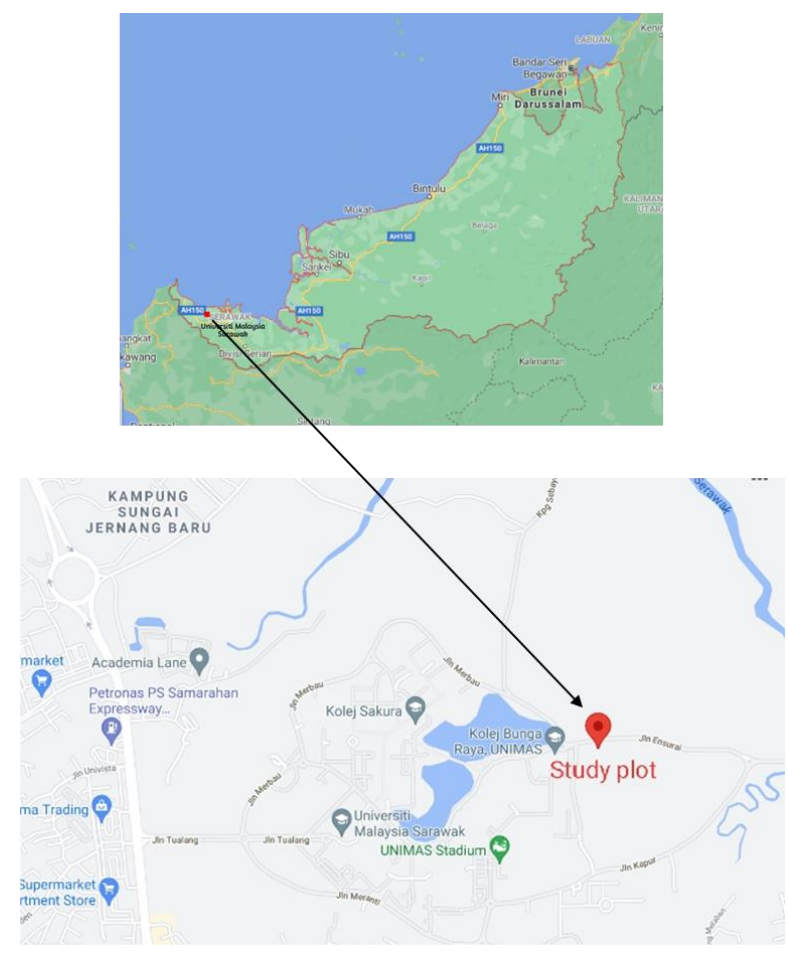

Figure 1 Map of the study area in Sarawak, East Malaysia (Source: Google Map 2021)

\subsection{Data collection}

DBH increment of 30 selected trees at secondary forest of UNIMAS were recorded monthly through the use of Series 5 Manual Band Dendrometer from AEC at the height of $1.3 \mathrm{~m}$ from the surface of the soil and for the period of 1 year as reported by [10]. The diameter of every selected tree was recorded at the initial and the following months. The monthly data of climatic elements such as rainfall, rain days, temperature, relative humidity, and solar radiation were collected from the Meteorology Department of Malaysia (Sarawak Branch).

\subsection{Data analysis}

The correlation of five climatic elements (rainfall, rain days, temperature, relative humidity, and solar radiation) and $\mathrm{DBH}$ increments of selected tree species were tested by Pearson correlation method. The multiple regression analysis was also used to relate five climatic elements and DBH increments.

\section{RESULTS AND DISCUSSION}

\subsection{Correlation between DBH increment and climate elements}

The diameter of the trees assessed ranged from $5.0 \mathrm{~cm}$ to $16.5 \mathrm{~cm}$. The correlation between DBH increments for the selected 30 trees and five climatic elements is as shown in Table 1. Positive correlation was found between average DBH increments for $M$. triloba, V. pubescens with rainfall ( $\mathrm{P}$ value $<0.01)$, while a negative correlation was observed with temperature and solar radiation $(\mathrm{P}$ value < 0.01). High amount of rainfall resulted in DBH increments for M. triloba, V. pubescens, and all sample trees while high temperature and solar radiation resulted in slow growth of these trees. Furthermore, a positive correlation $(\mathrm{P}$ value $<0.01$ ) was found between $\mathrm{DBH}$ increment for $\mathrm{E}$. diadenum and all sample trees with rain days, while a weak positive correlation $(\mathrm{P}$ value $<0.05)$ was found between DBH increments for C. arborescens, C. glaucum, and V. pubescens. These four selected tree species grew fast with high number of rain days. The average DBH increment of A. mangium showed negative correlation ( $\mathrm{P}$ value $<0.01$ ) to relative humidity and weak positive correlation $(\mathrm{P}$ value $<0.05)$ to solar radiation. A high DBH increment of A. mangium will be attained when low relative humidity and high solar radiation were recorded. The weak negative correlation was showed by $\mathrm{DBH}$ increment of $\mathrm{V}$. arborea and temperature ( $\mathrm{P}$ value $<0.05)$. The correlation between DBH increment of all sample trees and rainfall was weak and positive ( $\mathrm{P}$ value $<0.05)$. However, no correlation was discovered between average DBH increments of E. Glabra and M. gigantea and the five climatic elements.

Generally, positive correlations were observed between DBH increments of several selected tree species with rainfall and rain days. On the other hand, negative correlations were observed between DBH increments of several tree species with temperature, relative humidity, and solar radiation. Several studies on tree growth and climatic elements revealed that rainfall or precipitation and temperature are the two most important factors that affect tree growth [12] [13] [14] [15] [16].

These correlations affect the development of secondary forests especially at the end of the succession period. In addition, they are also important in estimating the transitional period of forest developmental stages. The result of this study has revealed that secondary forest growth will be affected by climatic elements during the process of succession. The existence of secondary forests needs more attention because they are expected to have the ability of reaching maturity although it may not be the same as the primary forests. 
Table 1. Pearson Correlation Coefficient of Five Climatic Elements With DBH Increment of Selected Tree Species

\begin{tabular}{|c|c|c|c|c|c|c|c|c|c|c|}
\hline \multirow{2}{*}{$\begin{array}{c}\mathrm{DBH} \\
\text { increment } \\
\text { (cm) }\end{array}$} & \multicolumn{2}{|c|}{$\begin{array}{l}\text { Rainfall } \\
\text { (mm) }\end{array}$} & \multicolumn{2}{|c|}{$\begin{array}{l}\text { Raindays } \\
\text { (days) }\end{array}$} & \multicolumn{2}{|c|}{$\begin{array}{c}\text { Temperature } \\
\left({ }^{\circ} \mathrm{C}\right)\end{array}$} & \multicolumn{2}{|c|}{$\begin{array}{l}\text { Relative humidity } \\
\text { (\%) }\end{array}$} & \multicolumn{2}{|c|}{$\begin{array}{l}\text { Solar radiation } \\
\qquad\left(\mathrm{MJ} \mathrm{m}^{2}\right)\end{array}$} \\
\hline & $r$ & Pvalue & $R$ & $P$ value & $r$ & Pvalue & $r$ & Pvalue & r & $P$ value \\
\hline $\begin{array}{l}\text { Acacia } \\
\text { mangium }\end{array}$ & -0.27 & 0.400 & -0.35 & 0.268 & 0.42 & 0.171 & $-0.74^{\star \star}$ & 0.006 & $0.59 *$ & 0.043 \\
\hline $\begin{array}{l}\text { Cratoxylum } \\
\text { arborescens }\end{array}$ & 0.29 & 0.369 & $0.59 *$ & 0.045 & -0.47 & 0.126 & -0.01 & 0.984 & -0.11 & 0.727 \\
\hline $\begin{array}{l}\text { Cratoxylum } \\
\text { glaucum }\end{array}$ & 0.25 & 0.438 & $0.58^{*}$ & 0.047 & -0.35 & 0.272 & 0.13 & 0.689 & -0.21 & 0.519 \\
\hline $\begin{array}{l}\text { Endospermu } \\
\text { m diadenum }\end{array}$ & 0.19 & 0.564 & $0.82^{* *}$ & 0.001 & -0.40 & 0.198 & 0.14 & 0.673 & -0.21 & 0.517 \\
\hline $\begin{array}{l}\text { Euodia } \\
\text { glabra }\end{array}$ & 0.12 & 0.715 & 0.54 & 0.069 & -0.26 & 0.407 & -0.13 & 0.695 & 0.09 & 0.791 \\
\hline $\begin{array}{l}\text { Macaranga } \\
\text { gigantea }\end{array}$ & 0.48 & 0.118 & 0.23 & 0.467 & -0.42 & 0.169 & 0.12 & 0.707 & -0.29 & 0.356 \\
\hline $\begin{array}{l}\text { Macaranga } \\
\text { triloba }\end{array}$ & $0.90^{* \star}$ & 0.000 & 0.34 & 0.275 & $-0.77^{\star \star}$ & 0.004 & 0.42 & 0.175 & $\begin{array}{c}- \\
0.81^{\star *}\end{array}$ & 0.001 \\
\hline $\begin{array}{l}\text { Vernonia } \\
\text { arborea }\end{array}$ & 0.41 & 0.183 & 0.58 & 0.046 & $-0.67^{\star}$ & 0.017 & 0.34 & 0.285 & -0.44 & 0.153 \\
\hline $\begin{array}{l}\text { Vitex } \\
\text { pubescens }\end{array}$ & $0.86^{* \star}$ & 0.000 & $0.58^{\star}$ & 0.050 & $-0.82^{* \star}$ & 0.001 & 0.40 & 0.194 & $\begin{array}{c}- \\
0.79 * *\end{array}$ & 0.002 \\
\hline $\begin{array}{l}\text { All sample } \\
\text { trees }\end{array}$ & $0.59 *$ & 0.043 & $0.78^{\star \star}$ & 0.003 & $-0.71^{\star \star}$ & 0.009 & 0.23 & 0.469 & -0.48 & 0.112 \\
\hline
\end{tabular}

Note: $\mathrm{r}$ are Pearson's correlation coefficients. $P$ values of correlations are shown. * and ${ }^{* *}$ correlations are significant at the 0.05 and 0.01 level (2tailed), respectively.

\subsection{Relationship between DBH Increment and Climate Elements}

Vegetation and climate interaction, particularly the DBH increment and climate elements, there is a need to identify relevant parameters of climate elements, those which describe and influence the DBH increment. A multiple regression analysis was used to describe the relationship between DBH increment of selected tree species and five climate elements. The five climate elements such as rainfall, raindays, temperature, relative humidity, and solar radiation were selected and used in this analysis. In this analysis the average DBH increments of selected tree species were monthly recorded by dendrometer as dependent variable (y), while rainfall $(\mathrm{x} 1)$, raindays $(\mathrm{x} 2)$, temperature $(\mathrm{x} 3)$, relative humidity (x4), and solar radiation $(\mathrm{x} 5)$ as independent variables $(\mathrm{x})$.

Table 2 shows the results of multiple regression analysis for relating $\mathrm{DBH}$ increment of selected tree species and climate elements. The results showed the average $\mathrm{DBH}$ increment of $E$. diadenum was significant to raindays $(\mathrm{P}$ value $<0.01)$, temperature $(\mathrm{P}$ value < $0.05)$, relative humidity $(\mathrm{P}$ value $<0.01)$, and solar radiation $(\mathrm{P}$ value $<0.05)$. The relationship of $\mathrm{DBH}$ increment of $E$. diadenum and climate elements was given by equation:

DBH increment of $E$. diadenum $=$ 
$0.02 \mathrm{RD}+0.06 \mathrm{~T}-0.03 \mathrm{RH}-0.03 \mathrm{SR}$

Note:

$$
\begin{array}{ll}
\mathrm{RD} & =\text { raindays }, \\
\mathrm{T} & =\text { temperature }, \\
\mathrm{RH} & =\text { relative humidity, } \\
\mathrm{SR} & =\text { solar radiation. }
\end{array}
$$

In this equation $\mathrm{F}$ value was 27.87 and $\mathrm{R}^{2}$ was 0.96 . The DBH increment of $E$. diadenum was linear with raindays and temperature, but contrast to relative humidity and solar radiation. The higher values of rainday and temperature were followed by the higher DBH increment of E. diadenum. On the other hand, the $\mathrm{DBH}$ of growth fastly as the values of relative humidity and solar radiation were low. Sometimes crop production is hampered due to very high or very low temperature during the growing period. But the primary constraint for crop production is the moisture. This depends entirely on rainfall. The rainfall is highly erratic and undependable [17].

The relationship between the average DBH increment of all sample trees and rain days was significant ( $\mathrm{P}$ value $<0.01)$. The average DBH increment of all sample trees, such as A. mangium, $C$. arborescens, C. glaucum, E. glabra, M. gigantea, M. triloba, V. arborea, and $V$. pubescens had no relationship to one or more climate elements. The analysis showed that almost all selected tree species were not significant related to five selected climate elements. This may caused of the analyzed climate data were for short-term period (12 months). The analysis used data of average monthly climate elements. Data of climate elements was not from the study site, but collected from the nearest station as mentioned earlier. These factors may influence to describe relationship between DBH increments of selected tree species with five climate elements.

Rainfall is a factor of prime significance for plants indirectly, but it is seldom a direct factor of importance. The total rainfall, and especially the distribution of rainfall through the year, is one of the leading features of climate, but the sufficient close figures can usually be obtained from the nearest rainfall station [18]. The most limiting factor is the moisture through rainfall [17] [19]. Crops depend on the rainfall for their moisture need. As far as the crop production is concerned, the distribution of rainfall is important rather than the quantity of rainfall in a locality. The distribution should be uniform to meet

\begin{tabular}{|c|c|c|c|c|c|c|c|c|c|}
\hline \multirow{3}{*}{$\begin{array}{l}\text { Dependent } \\
\text { variable (y) }\end{array}$} & \multirow{3}{*}{$\begin{array}{c}\text { No. of } \\
\text { measurement }\end{array}$} & \multirow[b]{3}{*}{ a $( \pm$ SE) } & \multirow[b]{3}{*}{$\begin{array}{c}P \\
\text { value }\end{array}$} & \multicolumn{6}{|c|}{ Independent variable (x) } \\
\hline & & & & \multicolumn{2}{|c|}{ Rainfall (mm) } & \multicolumn{2}{|c|}{ Raindays (days) } & \multicolumn{2}{|c|}{ Temperature $\left({ }^{\circ} \mathrm{C}\right)$} \\
\hline & & & & $b_{1}( \pm S E)$ & $P$ value & $\mathrm{b}_{2}( \pm \mathrm{SE})$ & $P$ value & $\mathrm{b}_{3}( \pm \mathrm{SE})$ & $\begin{array}{c}P \\
\text { value }\end{array}$ \\
\hline $\begin{array}{l}\mathrm{DBH} \\
\text { increment of } \\
\text { A. mangium }\end{array}$ & 12 & $0.80 \pm 0.64$ & 0.26 & $0.00 \pm 0.00$ & 0.90 & $0.00 \pm 0.00$ & 0.95 & $0.01 \pm 0.02$ & 0.61 \\
\hline $\begin{array}{l}\text { DBH } \\
\text { increment of } \\
\text { C.arborescens }\end{array}$ & 12 & $1.71 \pm 1.36$ & 0.25 & $0.00 \pm 0.00$ & 0.61 & $0.00 \pm 0.00$ & 0.25 & $-0.05 \pm 0.04$ & 0.21 \\
\hline $\begin{array}{l}\mathrm{DBH} \\
\text { increment of } \\
\text { C. glaucum }\end{array}$ & 12 & $0.38 \pm 2.09$ & 0.86 & $0.00 \pm 0.00$ & 0.89 & $0.01 \pm 0.00$ & 0.13 & $0.03 \pm 0.06$ & 0.68 \\
\hline $\begin{array}{l}\mathrm{DBH} \\
\text { increment of } \\
\text { E. diadenum }\end{array}$ & 12 & $1.48 \pm 0.76$ & 0.10 & $0.00 \pm 0.00$ & 0.16 & $0.02 \pm 0.00$ & $<0.001^{\star \star}$ & $0.06 \pm 0.02$ & $<0.05^{\star}$ \\
\hline $\begin{array}{l}\mathrm{DBH} \\
\text { increment of } \\
\text { E. glabra }\end{array}$ & 12 & $0.23 \pm 0.30$ & 0.48 & $0.00 \pm 0.00$ & 0.50 & $0.00 \pm 0.00$ & 0.13 & $-0.01 \pm 0.01$ & 0.45 \\
\hline
\end{tabular}
the water requirement at critical stages of crop growth.

Table 2. Multiple regression analysis of DBH increment of selected tree species and three climate elements (rainfall, raindays, temperature). 


\begin{tabular}{|c|c|c|c|c|c|c|c|c|c|}
\hline $\begin{array}{l}\mathrm{DBH} \\
\text { increment of } \\
\text { M. gigantea }\end{array}$ & 12 & $0.14 \pm 0.87$ & 0.88 & $0.00 \pm 0.00$ & 0.36 & $0.00 \pm 0.00$ & 0.81 & $-0.02 \pm 0.03$ & 0.49 \\
\hline $\begin{array}{l}\mathrm{DBH} \\
\text { increment of } \\
\text { M. triloba }\end{array}$ & 12 & $0.43 \pm 0.73$ & 0.58 & $0.00 \pm 0.00$ & 0.18 & $0.00 \pm 0.00$ & 0.88 & $-0.01 \pm 0.02$ & 0.70 \\
\hline $\begin{array}{l}\text { DBH } \\
\text { increment of } \\
\text { V. arborea }\end{array}$ & 12 & $1.72 \pm 1.60$ & 0.32 & $0.00 \pm 0.00$ & 0.95 & $0.00 \pm 0.00$ & 0.77 & $-0.06 \pm 0.05$ & 0.23 \\
\hline $\begin{array}{l}\mathrm{DBH} \\
\text { increment of } \\
\text { V.pubescens }\end{array}$ & 12 & $1.07 \pm 0.85$ & 0.26 & $0.00+0.00$ & 0.28 & $0.00+0.00$ & 0.12 & $-0.00+0.02$ & 0.96 \\
\hline $\begin{array}{l}\mathrm{DBH} \\
\text { increment of } \\
\text { all sample } \\
\text { trees }\end{array}$ & 12 & $0.85 \pm 0.43$ & 0.10 & $0.00 \pm 0.00$ & 0.44 & $0.00 \pm 0.00$ & $<0.01^{\star *}$ & $-0.01 \pm 0.01$ & 0.59 \\
\hline
\end{tabular}

Note: Significance levels are shown $* \mathrm{P}<0.05$ and $* * \mathrm{P}<0.01$. F value and coefficient of determination (R2) are provided.

Table 3. Multiple regression analysis of DBH increment of selected tree species and two climate elements (relative humidity and solar radiation).

\begin{tabular}{|c|c|c|c|c|c|c|c|}
\hline \multirow{3}{*}{ Dependent variable (y) } & \multirow{3}{*}{$\begin{array}{c}\text { No. of } \\
\text { measurement }\end{array}$} & \multicolumn{4}{|c|}{ independent variable $(\mathrm{x})$} & \multirow{3}{*}{$F$} & \multirow{3}{*}{$\mathrm{R}^{2}$} \\
\hline & & \multicolumn{2}{|c|}{ Relative humidity (\%) } & \multicolumn{2}{|c|}{ Solar radiation $\left(\mathrm{MJ} \mathrm{m}^{2}\right)$} & & \\
\hline & & $\mathrm{b}_{4}( \pm \mathrm{SE})$ & Pvalue & $b_{5}( \pm S E)$ & Pvalue & & \\
\hline DBH increment of $A$. mangium & 12 & $-0.01 \pm 0.01$ & 0.34 & $0.00 \pm 0.01$ & 0.64 & 1.71 & 0.59 \\
\hline DBH increment of $C$. arborescens & 12 & $-0.01 \pm 0.01$ & 0.56 & $0.02 \pm 0.02$ & 0.35 & 2.72 & 0.69 \\
\hline DBH increment of C. glaucum & 12 & $-0.01 \pm 0.02$ & 0.50 & $-0.01 \pm 0.03$ & 0.75 & 0.98 & 0.45 \\
\hline DBH increment of $E$. diadenum & 12 & $-0.03 \pm 0.01$ & $<0.01^{\star *}$ & $-0.03 \pm 0.01$ & $<0.05^{\star}$ & 27.87 & 0.96 \\
\hline DBH increment of E. glabra & 12 & $-0.00 \pm 0.00$ & 0.61 & $0.00 \pm 0.00$ & 0.31 & 2.60 & 0.68 \\
\hline DBH increment of $M$. gigantea & 12 & $0.00 \pm 0.01$ & 0.71 & $0.01 \pm 0.01$ & 0.42 & 0.63 & 0.35 \\
\hline DBH increment of $M$. triloba & 12 & $-0.00 \pm 0.01$ & 0.80 & $-0.00 \pm 0.01$ & 0.70 & 5.98 & 0.83 \\
\hline DBH increment of $V$. arborea & 12 & $-0.00+0.01$ & 0.86 & $0.01 \pm 0.02$ & 0.72 & 1.44 & 0.55 \\
\hline DBH increment of $V$. pubescens & 12 & $-0.01 \pm 0.01$ & 0.18 & $-0.01 \pm 0.01$ & 0.28 & 9.58 & 0.89 \\
\hline DBH increment of all sample trees & 12 & $-0.01 \pm 0.00$ & 0.07 & $-0.00 \pm 0.01$ & 0.69 & 11.56 & 0.91 \\
\hline
\end{tabular}

Note: Significance levels are shown $* \mathrm{P}<0.05$ and $* * \mathrm{P}<0.01$. F value and coefficient of determination (R2) are provided.

\section{CONCLUSION}

Diameter at breast height (DBH) increment of E. diadenum have influenced by climate elements on rainfalldays, temperature, relative humidity, and solar radiation.

\section{REFERENCES}

[1] Baker T R, Swaine M D and Burslem D F R P 2003 Variation in tropical forest growth rates: combined effects of functional group composition and resource availability Perspect. Plant Ecol. Evol. Syst. 6(1-2) 21-36

[2] Abazari B D and Talebi K H S 2008 Diameter and height increment process of oriental beech (Faglls 
orientalis) in natural caspian forests; Kelardasht region Iran. J. Forest and Poplar Research 15(4(30)) 320-28

[3] Toledo M, Poorter L, Peña-Claros M, Alarcón A, Balcázar J, Leaño $\mathrm{C}$, Licona $\mathrm{J} \mathrm{C}$, Llanque $\mathrm{O}$, Vroomans V, Zuidema P and Bongers F 2011 Climate is a stronger driver of tree and forest growth rates than soil and disturbance J. Ecol. 99 254-64

[4] Seydack A H W, Durrheim G and Louw J H 2011 Spatiotemporally interactive growth dynamics in selected south african forests: edaphoclimatic environment, crowding and climate effects Forest Ecol. Manag. 261 1152-69

[5] Lynch T B and Huebschmann M M 1992 Estimating diameter increment by DBH class with horizontal point sampling data Forest Ecol. Manag. 5 285-99

[6] Zudeima P A and Boot R G A 2002 Demography of the Brazil nut tree (Bertholletia excelsa) in the Bolivian Amazon: Impact of seed extraction on recruitment and population dynamics J. Trop. Ecol. $181-31$

[7] Sharma M 2021 Modelling climate effects on diameter growth of red pine trees in boreal Ontario, Canada Trees, Forests and People 4 1-20

[8] Fortin M, Van Couwenberghe R, Perez V and Piedallu C 2019 Evidence of climate effects on the height-diameter relationships of tree species Annals of Forest Science 76 (1) 1-29

[9] Remes J, Bilek L, Novak J, Vacek Z, Vacek S, Putalova T and Koubek L 2015 Diameter increment of beech in relation to social position of trees, climate characteristics and thinning intensity Journal of Forest Science 61 (10) 456-464

[10] Karyati, Ipor I B, Jusoh I and Wasli M E 2017 The diameter increment of selected tree species in a secondary tropical forest in Sarawak, Malaysia Biodiversitas 18 (1) 304-11

[11] Karyati 2013 Ecology and Carbon Sequestration of Secondary Forests at Sabal, Sarawak [Dissertation] (Malaysia: Universiti Malaysia Sarawak)

[12] Feliksik E and Wilczyński S 2009 The effect of climate on tree-ring chronologies of native and nonnative tree species growing under homogenous site conditions Geochronometria 33 49-57

[13] Maxime C and Hendrik D 2010 Effects on climate on diameter growth of co-occurring Fagus sylvatica and Abies alba along an altitudinal gradient Trees 25 265-76

[14] Rybníček M, Čermák P, Kolář T, Přemyslovska E and Žid T 2009 Influence of temperatures and precipitation on radial increment of Orlické hory $\mathrm{mts}$. spruce stands at altitudes over $800 \mathrm{~m}$ a.s.l. $J$. Forest Sci. 55 257-63

[15] Wei X, Yanhui W, Pengtao Y, Hallong L, Zhongjie S and Wei G 2007 Growth in stem diameter of Larix principis-rupprechtii and its response to meteorological factors in the south of Liupan Mountain, China Acta Ecol. Sin. 27(2) 432-41

[16] Yeh H and Wensel L C 2000 The relationship between tree diameter growth and climate for coniferous species in Northern California Can. J. For. Res. 30(9) 1463-71

[17] Gopalaswamy N 1994 Agricultural Meteorology (New Delhi: Rawat Publications)

[18] Tansley A G 1993 An Introduction to Plant Ecology (New Delhi: Discovery Publishing House)

[19] Nakasone H Y and Paull R E 1998 Tropical Fruits (United Kingdom: CAB International) 